\title{
Erratum to: The effects of rehabilitation on the muscles of the trunk following prolonged bed rest
}

\author{
Julie A. Hides · Gunda Lambrecht • Carolyn A. Richardson · \\ Warren R. Stanton - Gabriele Armbrecht • Casey Pruett • \\ Volker Damann · Dieter Felsenberg • Daniel L. Belavý
}

Published online: 13 August 2010

(C) Springer-Verlag 2010

\section{Erratum to: Eur Spine J}

\section{DOI 10.1007/s00586-010-1491-x}

In the footnote for Table 2, the $p$ value for the psoas muscle should read $p<.012$, not $p<.12$.

The online version of the original article can be found under doi:10.1007/s00586-010-1491-x.

J. A. Hides $(\bowtie)$. W. R. Stanton

School of Physiotherapy, Australian Catholic University,

McCauley Campus, PO Box 456, Virginia,

QLD 4014, Australia

e-mail: Julie.Hides@acu.edu.au

\section{J. A. Hides · W. R. Stanton}

Mater Health Services Brisbane Limited,

South Brisbane, QLD 4101, Australia

J. A. Hides - C. A. Richardson

Division of Physiotherapy, School of Health and Rehabilitation

Sciences, The University of Queensland, Brisbane,

QLD 4072, Australia

G. Lambrecht

Krankengymnastikpraxis, Kaiserstraße 34,

53721 Siegburg, Germany

G. Armbrecht · D. Felsenberg · D. L. Belavý

Zentrum für Muskel- und Knochenforschung,

Charité Campus Benjamin Franklin, Hindenburgdamm 30,

12200 Berlin, Germany

\section{Pruett}

Wyle Laboratories GmbH, Albin-Koebis Strasse 4,

51147 Cologne, Germany

\section{Damann}

European Astronaut Center, European Space Agency,

Linder Hoehe, 51147 Cologne, Germany 